\title{
UPAYA PENINGKATAN PENDAPATAN RUMAH TANGGA \\ MELALUI PENGEMBANGAN USAHA PADA KELOMPOK PENGRAJIN BATIK TULIS KAMPOENG BATIK DESA KARASKEPOH KABUPATEN REMBANG
}

\author{
Riskin Hidayat dan Siti Alliyah \\ Sekolah Tinggi Ilmu Ekonomi 'YPPI' Rembang \\ email: rieskqien@yahoo.co.id \\ email: wildankafa@yahoo.co.id
}

\begin{abstract}
Key word:
Local Wisdom, Counseling, Training, Assistance business, Promotion media, Feasibility proposal, Bookkeeping.
\end{abstract}

\begin{abstract}
The program IbM is implemented in the Karaskepoh village, Pancur district, Rembang with partners Craftsmen Group Batik Sekar Melati and Sekar Jagad. Karaskepoh village is one of the tourist village kampoeng batik in Rembang because many of its citizens who work as batik, so local knowledge is necessary to get attention in IbM program. IbM purpose of this is to increase revenue Craftsmen Group Batik Sekar Melatiand Sekar Jagad. The methodology carried out is counseling, training of Management and Entrepreneurship, and business assistance. IbM program results include: 1) There is an increasing role of group members batik andbusiness networking; 2) Batik products Sekar Melati and Sekar Jagat group has had a more diverse media promotion, both conventional ones such as brochures, business cards, and banners although online media promotions is using a blog; 3) Batik products Sekar Melati and Sekar Jagad group has had packaging and labels a good and interesting; 4) Group batik Sekar Melati and Sekar Jagat has had a good product catalog; 5) It has been structured proposal batik feasibility Sekar Melati and Jagad Sekar group; and 6) The group batik Sekar Melati and Sekar Jagat has had an orderly and good bookkeeping.
\end{abstract}

\begin{abstract}
Abstrak
Program IbM dilaksanakan di desa Karaskepoh, Kecamatan Pancur, Rembang dengan mitra Pengrajin Grup Batik Sekar Melati dan Sekar Jagad. Desa Karaskepoh merupakan salah satu desa wisata kampoeng batik di Rembang Tujuan pengabdian ini untuk meningkatkan pendapatan Pengrajin Grup Batik Sekar Melati dan Sekar Jagad. Metodologi yang dilakukan adalah penyuluhan, pelatihan Manajemen dan Kewirausahaan, dan bantuan usaha. Hasil Program IbM meliputi: 1) Ada peningkatan peran anggota kelompok batik dan jaringan bisnis; 2) Produk Batik Sekar Melati dan Sekar Jagat memiliki media promosi yang lebih beragam, baik yang konvensional seperti brosur, kartu nama, spanduk dan media online blog; 3) Produk Batik Sekar Melati dan Sekar Jagad kelompok yang memiliki kemasan dan label yang baik dan menarik; 4) Memiliki katalog produk yang baik; 5) Telah terstrukturkelayakan usulan batik Sekar Melati dan kelompok Jagad Sekar; dan 6) Kelompok batik Sekar Melati dan Sekar Jagat telah memiliki pembukuan yang tertib dan baik
\end{abstract}

